\title{
Autologous Stem Cell Transplantation as the First-Line Treatment for Peripheral T Cell Lymphoma: Results of a Comprehensive Meta-Analysis
}

\author{
J.Yin J.Wei J.H.Xu Y.Xiao Y.C.Zhang \\ Department of Hematology, Tongji Hospital, Tongji Medical College, Huazhong University of Science and \\ Technology, Wuhan, China
}

\section{For editorial comment see p. 112}

\section{Key Words}

Autologous stem cell transplantation · Meta-analysis .

Peripheral T cell lymphoma

\begin{abstract}
Objective: In view of the poor prognosis of most peripheral T cell lymphoma (PTCL) subtypes treated with conventional chemotherapy such as CHOP/CHOP-like regimens, highdose chemotherapy followed by autologous stem cell transplantation (HDT/ASCT) seems a reasonable option in eligible patients. Nevertheless, owing to the small size of the study and the heterogeneity of most published series, a consensus on the role of ASCT as the first-line consolidation therapy for high-risk PTCL patients has not been reached so far. Study Design: We searched MEDLINE, EMBASE, EBSCO, Web of Science, clinicaltrials.gov and the Cochrane Library. Hazard ratio (HR) and 95\% confidence intervals (Cls) were calculated by a fixed/random effect model. Results: Twenty-one studies were eligible. Although no statistical significance was observed in these studies, there was a trend toward survival advantage for the HDT/ASCT group as compared to the historical control group (HR 0.81, 95\% Cl 0.31-2.13). Statistical differences were confirmed in terms of overall survival (OS) between complete remission (CR) and non-CR patients (HR $3.17,95 \% \mathrm{Cl}$ 0.92-5.42), patients with good and poor risk according to the International Prognostic Index (IPI; HR 0.36,
\end{abstract}

95\% Cl 0.22-0.60, $\mathrm{I}^{2} 49 \%$ ) and Prognostic Index for PTCL (PIT; HR 0.31, 95\% Cl 0.17-0.58; HR 0.31, 95\% Cl 0.18-0.54). Conclusion: The clear and convincing proof of the effects of upfront HDT/ASCT still depends on sufficient large PTCL-restricted randomized trials in the future. Patients who failed to attain CR before transplant exhibited a worse prognosis; patients with good risk of IPI or PIT had a substantially better OS after ASCT.

(C) 2013 S. Karger AG, Basel

\section{Introduction}

Peripheral T cell lymphoma (PTCL) is a small heterogeneous subgroup of non-Hodgkin's lymphoma (NHL). Though clinical characteristics vary with different PTCL subgroups, patients with PTCL tend to have older age, higher frequency of constitutional symptoms, extranodal disease, a lower performance status, and an elevated serum lactate dehydrogenase (LDH) $[1,2]$. The prognosis for most PTCL subtypes is generally poor with a 5-year survival of less than $30 \%$ and a median survival of $20-34$ months [3]. Despite the disappointing outcome of anthracycline-based chemotherapy in PTCL patients compared to aggressive B cell NHL, such regimens, especially CHOP, have remained the standard treatment for PTCL [4-8]. In the largest study with 288 PTCL patients treated with dif-

\section{KARGER}

E-Mail karger@karger.com

www.karger.com/aha
() 2013 S. Karger AG, Basel

$0001-5792 / 14 / 1312-0114 \$ 39.50 / 0$
Prof. Y.C. Zhang

Department of Hematology, Tongji Hospital

Tongji Medical College, Huazhong University of Science and Technology

1095 Jie-Fang Avenue, Wuhan 430030 (China)

E-Mail yczhang@tjh.tjmu.edu.cn 
ferent anthracycline-based regimens, the 5-year overall survival (OS) and event-free survival (EFS) were 41 and $33 \%$, respectively, which were significantly worse than those of diffuse large B cell lymphomas (DLBCL) [5]. Similarly, some studies came to the conclusion that even intensified chemotherapy approaches failed to improve the outcomes of PTCL, and the 5-year OS remained between 25 and $40 \%[4,9,10]$. Given the limited success of conventional chemotherapy in the majority of PTCL patients, high-dose chemotherapy followed by autologous stem cell transplantation (HDT/ASCT) has been investigated at many institutions worldwide. The impact of HDT/ASCT, which is considered the standard treatment in relapsed aggressive B cell lymphoma, has shown efficacy as a salvage therapy in PTCL [11-21]. However, this strategy as the first-line treatment is a matter of debate which has not been concluded yet because there have been no randomized prospective studies exclusively in patients with PTCL. In recent years, several retrospective and prospective trials have been published evaluating the role of ASCT as part of the first-line therapy in PTCL patients. However, these studies were limited by small sample sizes and case composition with various histologies [22-39]. Therefore, it is difficult to draw definitive conclusions regarding the efficacy of ASCT. Here, we perform a meta-analysis in order to determine whether PTCL patients could benefit from first-line therapy consolidation with ASCT.

\section{Methods}

\section{Literature Search Strategy}

Studies were identified by searching MEDLINE, EMBASE, EBSCO, Web of Science, clinicaltrials.gov and the Cochrane Library. References mentioned in reviews and other published systematic reviews were also hand searched. All searches were conducted for the period between 1990 and 2012.

\section{Study Selection}

Studies were eligible for enrollment in the meta-analysis if they met all of the following criteria: (1) diagnoses were rendered according to the WHO classification; (2) the studies were published between January 1990 and July 2012 as an original article written in English; (3) the studies dealt with adult patients with PTCL followed by autologous stem cell transplantation; (4) the study patients were to be treated with HDT/ASCT as part of the first-line therapy; (5) the median follow-up time was at least 12 months; (6) the studies provided data on survival outcomes (OS) and/or hazard ratios (HRs) and 95\% confidence intervals (95\% CIs) for OS; (6) they were not presented as case reports, abstracts or reviews, and (7) they were published in full with available data, either published or retrieved through personal communication. Studies were carefully screened for possible duplication of study populations based on the participating institutions and period of presentation of patients.

ASCT as the First-Line Treatment for

PTCL: Meta-Analysis Results

\section{Data Extraction}

Two reviewers independently extracted data from the articles and subsequently compared the results. Any disagreement was solved by discussion. Extracted data included the name of the first author, year of publication, study name, PTCL subtype, number of patients, age, criteria for study entry, median follow-up time, disease status at diagnosis, disease status at ASCT, number of patients in different remission statuses at transplantation, and HRs and 95\% CIs for OS. When the data required for the analysis could not be extracted from the articles, corresponding authors were contacted for missing data and additional information regarding the studies.

\section{Outcomes Measures}

OS were measured from the time of transplantation to death from any cause, and surviving patients were censored at last follow-up. Complete remission (CR) was defined as total disappearance of all evidence of tumor and partial remission (PR) as a $>50 \%$ reduction in the sum of the products of the longest diameters of measurable lesions.

\section{Statistical Analysis}

The primary outcomes in our study were OS. HR was the preferred summary statistic for reporting time-to-event data. For most of the eligible studies, HRs for survival could not be directly extracted from the original articles. Accordingly, available data were extracted from the original paper to calculate HR and standard error using the method of Parmar et al. [40] and Tierney et al. [41]. For each analysis, a forest plot was generated to display results. Heterogeneity existed when the $\mathrm{p}$ value of Cochran's $\mathrm{Q}$ test was $<0.1$ and the $\mathrm{I}^{2}$ statistic was $>50 \%$ [42]. If significant heterogeneity existed, a random-effect model was used to pool the data; otherwise a fixed-effect model would be used. All meta-analyses were completed using Review Manager (v.5.1, The Cochrane Collaboration, Oxford, UK) and Stata v.11.0 software (College Station, Tex., USA). Statistical significance was defined as a p value $<0.05$ for all tests except those for heterogeneity and publication bias [43].

\section{Results}

\section{Characteristics of the Studies}

Our comprehensive search of MEDLINE, EMBASE, EBSCO, Web of knowledge, clinicaltrials.gov and the Cochrane Library identified 1,500 references as relevant. After screening the title and abstract of those studies, 1,318 studies were excluded because of duplication and irrelevance. After more detailed evaluation, 156 studies were excluded for not meeting the criteria (fig. 1). Ultimately, 21 studies with 1,021 PTCL patients who were treated with HDT/ASCT as part of the first-line therapy were used in the meta-analysis. All of the studies were published in full text. The characteristics of these 21 studies are described in table 1. Studies including both patients receiving ASCT as first-line and salvage therapy are listed 
Fig. 1. Study selection for the systematic review and meta-analysis.

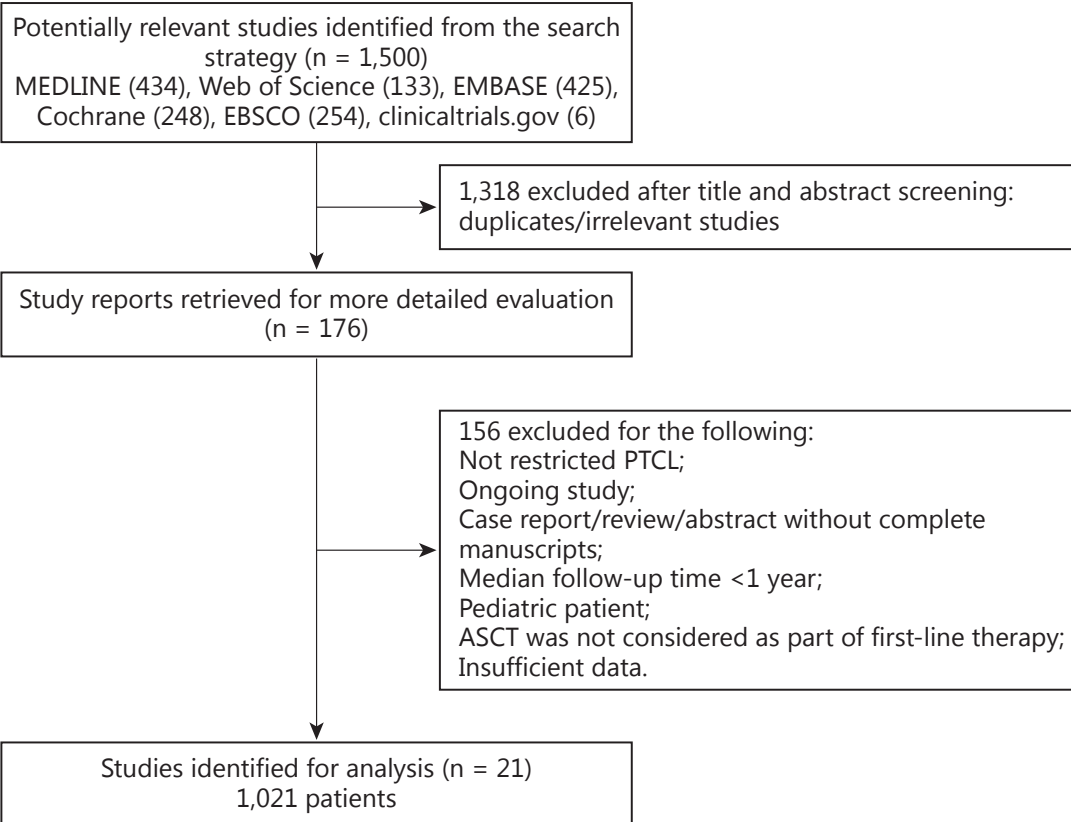

in the table representing the predominant group. The median age ranged from 36 to 59 years. The sample sizes ranged from 10 [23] to 166 [44] patients. In one study only patients with PR were included [45], and in another study the patients with CR were selected [29]. In the remaining studies, patients were enrolled irrespective of their remission status. A variety of induction, high-dose therapy regimens and conditioning regimens were used in the chemotherapy arms and transplantation (table 1).

\section{Overall Survival}

Among the 21 studies enrolled, the OS of patients receiving HDT/ASCT as part of front-line treatment ranged from $58 \%$ at 1 year to $34 \%$ at 12 years. The CR rate after ASCT ranged from 59 to $100 \%$. Among the studies which provided both OS and its 95\% CI, 5-year OS and its 95\% CI were obtained from 5 studies [22, 29, 38, 44, 45]. The summary estimated 5-year probabilities of OS of patients who transplanted as front-line therapy was $62 \%$ (95\% CI 0.44-0.80; fig. 2).

In the comparison of OS between the group of patients treated with up-front HDT/ASCT and with conventional chemotherapy alone, 4 studies with a total of 606 patients were used for meta-analysis [26, 32, 34, 36]. However, in the study reported by Niitsu et al. [34], the patients with chemotherapy alone were divided into $\mathrm{CHOP}$ and $\mathrm{Cy}$ -
clOBEAP subgroups, and the comparisons were drawn respectively. Therefore, a total of 5 sets of data were used for analysis. The random effect estimate of the HR for OS for the 4 studies was 0.81 (95\% CI 0.31-2.13, $\left.\mathrm{I}^{2} 77 \%\right)$. Although the survival benefits from the HDT/ASCT were unconfirmed by statistics $(\mathrm{p}=0.66)$, the trend that HDT/ ASCT achieved better therapeutic effect than chemotherapy alone is shown in figure 3 .

\section{Remission Status at Transplantation}

Comparisons of OS among the patients with different remission statuses at transplantation were made in 8 studies [25-28, 31, 36-38]. The remission statuses at transplantation were assessed according to the International Working Group criteria [46]. Three studies with 149 PTCL patients were used in this meta-analysis and $\mathrm{HR}$ in multivariate analysis for OS between patients in CR and in non-CR at transplantation were provided $[25,37$, 38]. The summary-estimated HR for OS was 3.17 (95\% CI $\left.0.92-5.42, \mathrm{I}^{2} 0.0 \%\right)$. The patients in CR at the time of transplantation showed a definite survival advantage compared with patients in non-CR at transplantation $(\mathrm{p}=0.004)$. In addition, the estimated HR for OS extracted from 3 studies $[28,36,37]$ in patients in CR compared to patients in $\mathrm{PR}$ at transplantation was 0.73 (95\% CI $\left.0.36-1.48, \mathrm{I}^{2} 0.0 \%\right)$ indicating that patients in CR at trans- 




Fig. 2. Meta-analysis of 5-year OS of patients undergoing HDT/ASCT as the front-line therapy.

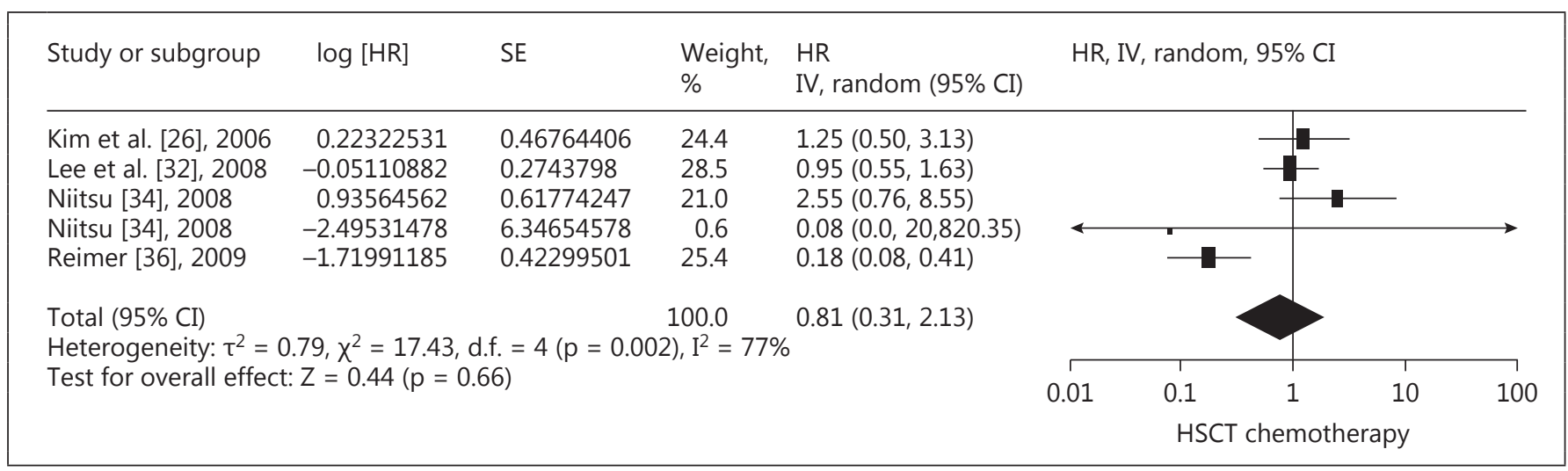

Fig. 3. Meta-analysis of the HRs of OS in patients with PTCL treated with HDT/ASCT in comparison with patients receiving conventional chemotherapy. Solid squares indicate the HRs of each study. The size of the squares is proportional to the sample size and the horizontal lines denote $95 \%$ CIs. The diamond shows the CI for the pooled HRs. HSCT = Hematopoietic stem cell transplantation.

plantation did not obtain better outcomes than patients in PR (fig. 4). In the remaining studies, 1 study provided HR in univariate analysis [36], 1 study compared OS between patients in CR1/PR1 and CR2/PR2 [38], and 3 studies provided comparisons between different statuses separately. Because of inconsistencies of grouping, these studies cannot be used for analysis.

\section{Impact of Risk Factors on OS}

Among the patients treated with HDT/ASCT, analysis of OS in terms of the International Prognostic Index (IPI) at diagnosis was reported in 9 studies $[23,25,28,30,36-$ $39,45]$. Six studies, including 347 patients, were enrolled in this meta-analysis $[23,28,36,38,39,45]$. The summary-estimated HR for OS was 0.36 (95\% CI $0.22-0.60, \mathrm{I}^{2}$
$49 \%$ ), as determined with the fixed-effect model, suggesting a significant survival advantage after transplantation for patients with low IPI risk compared to patients with high IPI risk ( $\mathrm{p}<0.0001$; fig. 5).

Likewise, the Prognostic Index for PTCL (PIT) subgroup analyses were based on 4 studies according to stratification from the original articles [28, 29, 36, 37]. Two studies with 99 patients who received HDT/ASCT were used to analyze the OS in patients with PIT $<2$ and patients with PIT $\geq 2$. Another 2 studies with 157 patients were used to compare the OS in patients with PIT $<3$ and patients with PIT $\geq 3$. Among these, the study by Yang et al. [37] analyzed OS in patients with PIT 2-3 in comparison with patients with PIT 0 and PIT 1 , respectively. The summary HRs for OS in patients with different PIT 


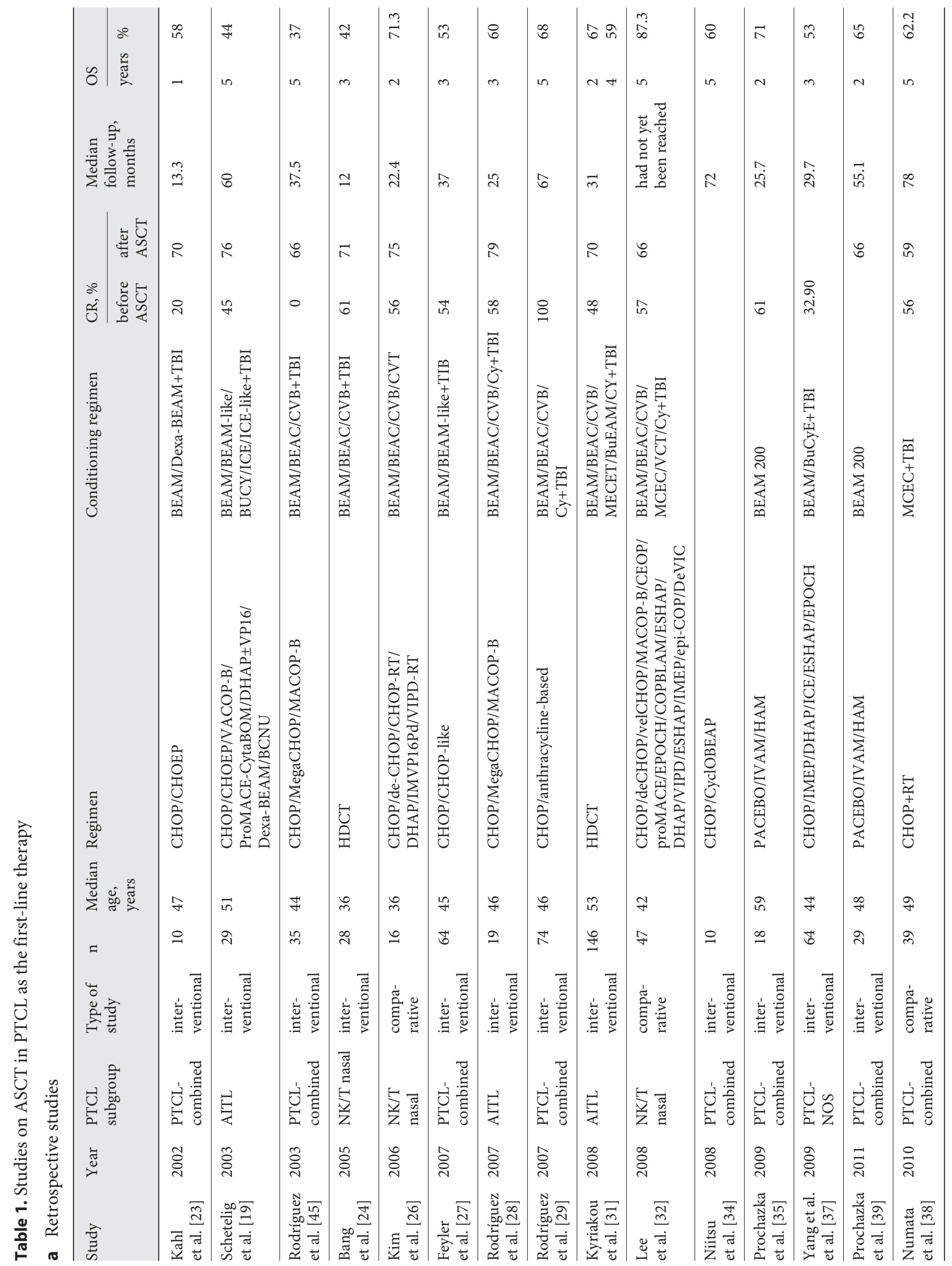




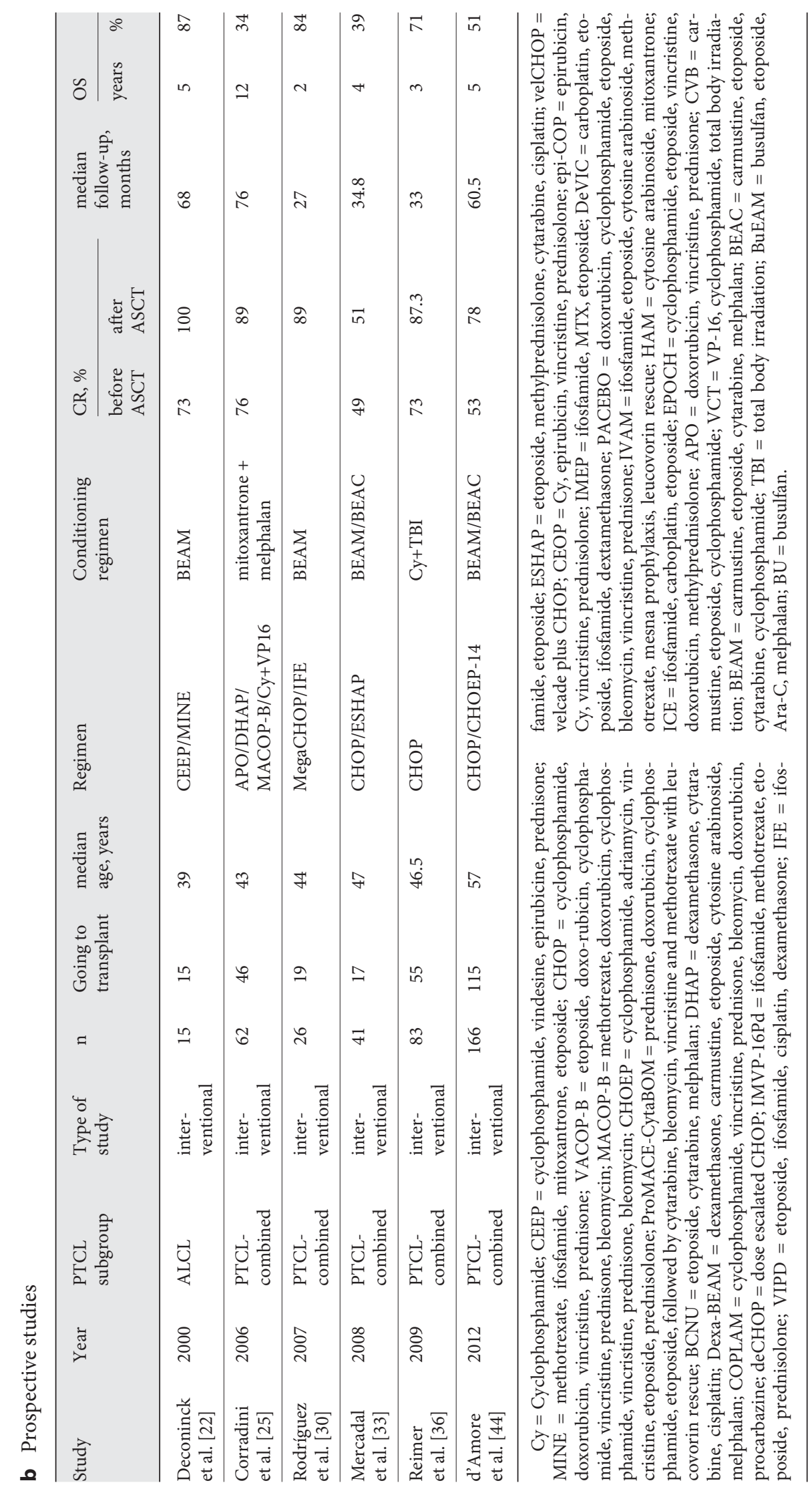




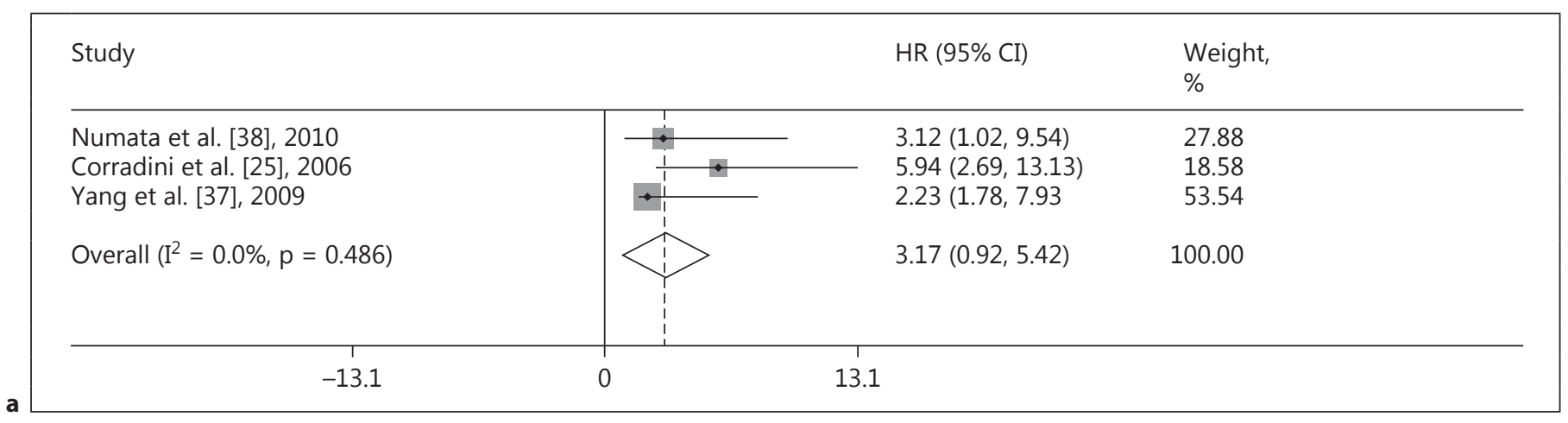

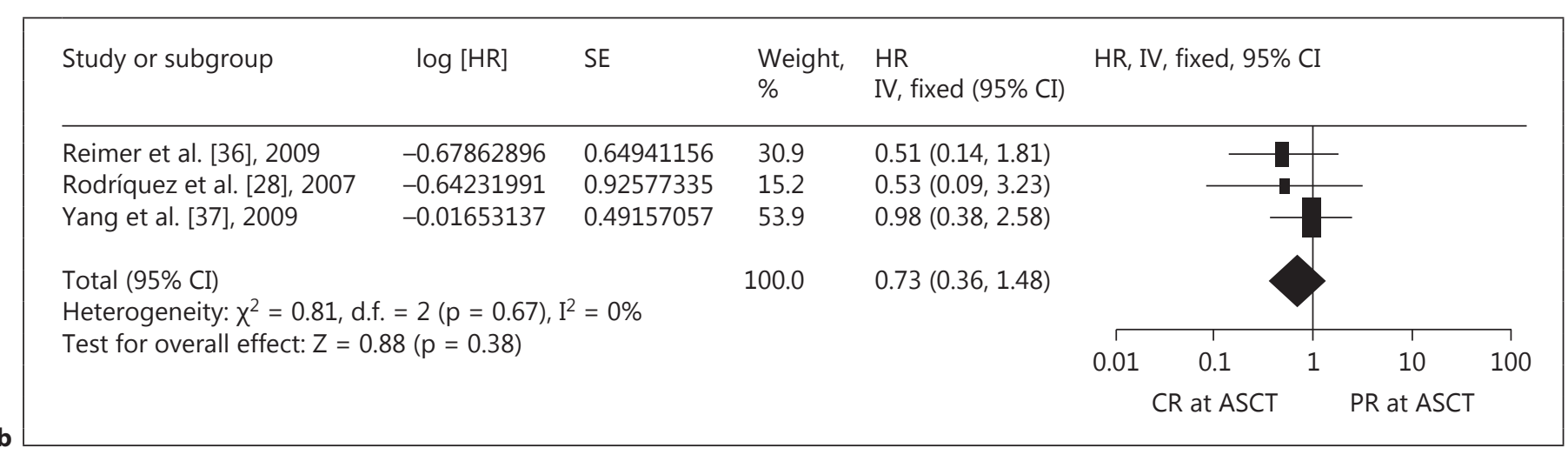

Fig. 4. a Meta-analysis of the HRs of OS in patients with PTCL in CR in comparison to non-CR patients at the time of transplantation. b Meta-analysis of the HR of OS in patients with PTCL in CR in comparison to PR patients at the time of transplantation.

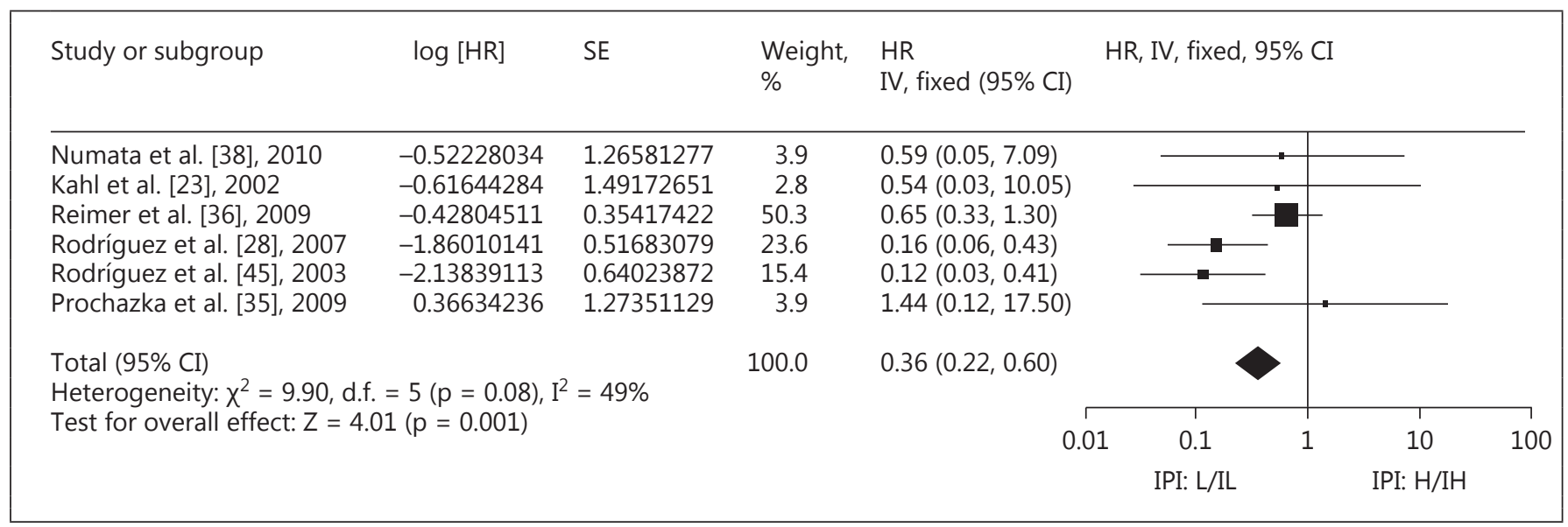

Fig. 5. Meta-analysis of the HRs of OS in patients with good risk of IPI in comparison to patients with poor risk of IPI. 


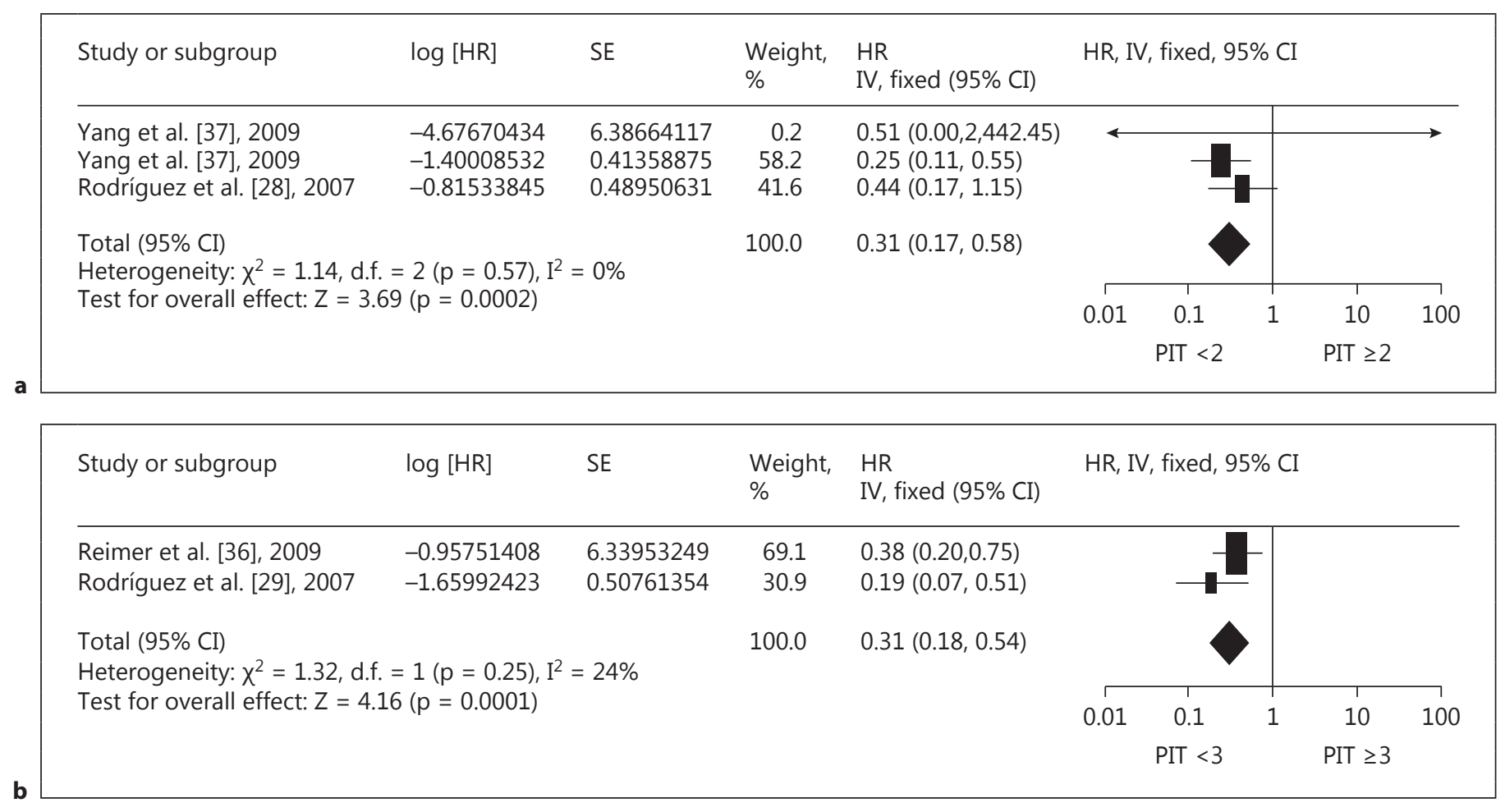

Fig. 6. Meta-analysis of the HRs of OS in patients from different PIT subgroups.

groups were $0.31\left(95 \% \mathrm{CI} 0.17-0.8, \mathrm{I}^{2} 0 \%\right)$ and $0.31(95 \%$ CI $\left.0.18-0.54, \mathrm{I}^{2} 24 \%\right)$, indicating that patients with lower scores of PIT had better outcomes compared with patients with higher scores of PIT (fig. 6).

\section{Discussion}

PTCL is less responsive to and has less frequent durable remissions with chemotherapy regimens such as $\mathrm{CHOP}$ and more intensive regimens such as hyper-CVAD. This meta-analysis reviewed 21 studies with 1,021 patients to evaluate the effects of HDT/ASCT in the first-line treatment in PTCL from different perspectives. The CR rate after ASCT ranged from 51 to $100 \%$. The OS in those studies ranged from $58 \%$ at 1 year to $34 \%$ at 12 years. In this meta-analysis, a summary-estimated 5-year OS of $62 \%$ was revealed. Currently, some studies have suggested that HDT/ASCT might be superior to conventional chemotherapy [24, 27, 28, 32, 36, 37]. However, the studies supporting this were limited by small size and it is difficult to evaluate the clinical effect of HDT/ASCT from single-center research. Among the published studies which made comparisons between up-front HDT/ASCT and chemo- therapy alone in PTCL patients, 4 studies with a total of 128 PTCL patients treated with up-front HDT/ASCT and 468 patients who received conventional chemotherapy were enrolled in this analysis. Therefore, we combined these 4 studies to perform a meta-analysis. Unfortunately, according to our pooled results, no significant difference existed for HDT/ASCT to improve OS. Nevertheless, a trend of advantage for the patients with HDT/ASCT over those with chemotherapy alone can be seen in figure 2 . The studies reported by Lee et al. [32] and Reimer et al. [36] with larger sample sizes provided statistics to prove the survival benefits from HDT/ASCT in comparison to chemotherapy alone. The study by Reimer et al. [36] was one of the first prospective multicenter trials that evaluated the role of HDT/ASCT as upfront therapy for PTCL. Eighty-three patients with primary diagnosed PTCL were enrolled and the median age was 46.5 years (range 30-65). Sixty-two patients had advanced disease (Ann Arbor stage III or IV) and 49 patients complained of 'B' symptoms. The treatment regimen consisted of four to six cycles of CHOP followed by HDT/ASCT. With a median follow-up of 33 months, the 3 -year OS rate was $71 \%$ for patients who underwent ASCT compared with only $11 \%$ for patients who did not undergo ASCT. This study excluded anaplas- 
tic lymphoma kinase (ALK)-positive anaplastic large cell lymphoma (ALCL) cases so that a potential OS bias toward a survival benefit caused by including ALK-positive ALCL could be ruled out. In the study reported by Lee et al. [32], a total of 47 patients who underwent ASCT were compared with 107 matched controlled cases. The median age was 47 years (range 17-80). All clinical parameters except age and initial Ann Arbor stage were relatively well balanced between the control group and the study group. Although the median survival time was not determined for the HDT/ASCT group after a median follow-up of 116.5 months, the impact of HDT/ASCT on the survival of patients was significantly improved with a 2.1-fold reduced risk of death. There were limited cases treated with HDT/ASCT in the studies reported by Kim et al. [26] and Niitsu et al. [34]. The study reported by Kim et al. [26] included 16 extranodal NK/T cell lymphoma patients who received HDT/ASCT and 246 patients who did not receive transplantation. At diagnosis, half of the patients were at an advanced stage (Ann Arbor stage III-IV). The median age was 36 years (range 17-54). The estimated 2-year OS was $71.3 \pm 12.4 \%$ in patients with HDT/ASCT and $56.5 \pm 3.3 \%$ in the 246 patients who did not receive HDT/ ASCT. Also, in the study reported by Niitsu et al. [34], CHOP therapy was performed in 55 cases in patients with PTCL-U or angioimmunoblastic T cell lymphoma, CyclOBEAP therapy in 32 cases and ASCT in 10 cases. The 5 -year OS among those who received CHOP therapy, CyclOBEAP therapy or ASCT was 25.7, 61.7 and 60\%, respectively. Although no statistical significance was observed in these studies, the authors regarded that there was a trend toward survival advantage for the HDT/ASCT group as compared to the historical control group. Furthermore, in the largest study with 288 PTCL patients treated with different anthracycline-based regimens, the 5 -year OS was $41 \%$ [5], and according to a published meta-analysis of front-line anthracycline-based chemotherapy regimens for PTCL, which included 31 studies, the 5 -year OS for all PTCL patients $(\mathrm{n}=1,691)$ was $36.6 \%$ (95\% CI 31.5-42.0) [47]. Compared with the 5-year OS of $65 \%$ in this meta-analysis, it seems that the up-front ASCT provides a better survival outcome. Although a statistic survival benefit of HDT/ASCT as the first-line therapy could not be proven in this meta-analysis, evidences to support the survival advantages of up-front HDT/ASCT are beginning to emerge as more clinical studies are reported. In general, the clear and convincing proof about the effects of up-front HDT/ASCT still depends on sufficient PTCL-restricted randomized trials with large size being carried out in the future.
Despite the fact that there was no evidence for HDT/ ASCT to improve OS in patients, there were some differences between risk groups stratified according to disease status at transplantation, the IPI and PIT. Good-risk patients, i.e. those with low or low-intermediate risk according to IPI and PIT and those achieving CR before transplantation, showed evidence for improved OS with HDT/ ASCT.

The outcomes after HDT/ASCT always correlate with the disease status at the time of transplantation, which can be regarded as a significantly independent prognostic factor $[13,25,28,29,31,36,37]$. The achievement of CR before transplantation was a strong predictor of survival benefit. Our meta-analysis strengthens the proposal that survival outcomes are dismal if the patient failed to attain CR before transplantation. We also found that patients in CR and patients in PR at transplantation showed no statistical difference in OS. Consequently, patients with PTCL should be brought into remission with optimal chemotherapeutic regimens. When this is attained, the use of ASCT to consolidate responses could lead to good long-term post-transplant survival. In cases where remission cannot be attained, ASCT rescues only a handful of patients. Hence, novel treatment concepts incorporating novel agents and dose-dense regimens are needed to increase the $\mathrm{CR}$ rate prior to transplantation.

IPI was originally developed for the aggressive B cell lymphomas and is commonly used in PTCL. PIT was specifically developed for PTCL. Both IPI and PIT have shown prognostic value in PTCL and determine the outcome of patients with PTCL in many studies [2, 48-55]. OS benefit from HDT/ASCT was mainly demonstrated for high/intermediate-risk patients but not for low-risk patients compared with chemotherapy. In this metaanalysis, statistical differences obtained from enrolled studies showed that patients with good risk of IPI or lower scores of PIT before transplantation showed considerably better outcomes after ASCT. Nevertheless, these results can be understood with the fact that high-risk patients remain at high risk even after ASCT. In the studies reported by Kim et al. [26] and Lee et al. [32], further analyses of OS between HDT/ASCT and chemotherapy subgroups were performed in terms of good and poor risk of IPI. Despite high-risk IPI groups that underwent HDT/ ASCT having more prolonged survival, no statistical significance was revealed. These results were inconsistent with those of previous studies. The limitation that PIT and IPI subgroup comparisons are hampered by their variety of grouping should be taken into consideration. In addition, given that the IPI and PIT failed to demonstrate 
prognostic value in some studies $[13,27,30]$, a new prognostic model was developed by the International Peripheral T Cell Lymphoma Project (IPTCLP). Definite survival benefit of HDT/ASCT either in high-risk or low-risk patient subgroups needs more randomized trials to be proven to be true, and the prognostic value of IPI and PIT for PTCL should be further studied. However, the latest and largest multi-center clinical trial, reported by d'Amore et al. [44], found the IPI to prognosticate effectively in angioimmunoblastic T cell lymphoma and PTCL-NOS, but not in ALK-negative ALCL. Furthermore, considering individual clinicopathologic features, those significantly affecting OS and/or progression-free survival at both univariate and multivariate levels were female sex and ALCL histology associated with favorable outcome, and age, bone marrow involvement and PS $\geq 2$ as adverse prognosticators.

There are some limitations of our meta-analysis. First of all, since this meta-analysis was mainly based on retrospective studies, results can only be suggested and not proven. Further prospective studies would therefore be necessary. Secondly, we failed to get all the details of the patients that were available from the published studies or through contacting the authors, meaning we only used abstracted data although those details would have provided a more robust estimate of the efficacy of up-front HDT/ASCT. Our meta-analyses pooled the best available data from existing publications on the treatment of PTCL and the random effects model was chosen to enhance the stability of the statistics. However, we did not perform Jadad scoring of individual trials in this meta-analysis because there were no randomized PTCL-restricted clinical trials and most series were of a small size [56]. As a result, heterogeneity problems were inevitable. We did not take the impact of the histological subtype on ASCT under consideration. Thus, our comparison is biased by this lack of information. In addition, some studies included ALCL patients with ALK+ or patients with NK/T cell lymphoma, who generally showed favorable outcomes. Taking this into account, there would be a tendency to bias OS toward a benefit. Finally, studies reporting positive or significant findings are more likely to be published than those reporting nonsignificant results. Therefore, publication bias is a major concern in all meta-analyses. To better define the role of HDT/ASCT, the data from the unpublished trials should be made available for a more complete assessment of the treatment effect.

In conclusion, up-front HDT/ASCT failed to show a survival benefit in PTCL patients compared with conventional chemotherapy alone based on our statistical results. However, HDT/ASCT is considered a reasonable approach in eligible patients with PTCL, especially in patients achieving CR after induction therapy. Also, low PIT or IPI score could be regarded as favorable prognostic factors for OS. Taking into account that most of these studies had heterogeneous weakness and different trial designs, definitive treatment recommendations would seem to depend on large-scale, high-quality multinational randomized PTCL-restricted clinical studies.

\section{Acknowledgments}

The authors would like to thank Dr. Peter Reimer for providing detailed information regarding the survival analysis of his study.

This study was supported by two grants from the National Science Foundation of China (30971293 and 30670897).

\section{References}

1 Coiffier B, Brousse N, Peuchmaur M, Berger F, Gisselbrecht C, Bryon PA, Diebold J: Peripheral T-cell lymphomas have a worse prognosis than B-cell lymphomas: a prospective study of 361 immunophenotyped patients treated with the LNH-84 regimen. Ann Oncol 1990; 1:45-50.

-2 Vose J, Armitage J, Weisenburger D: International peripheral $\mathrm{T}$-cell and natural killer/Tcell lymphoma study: pathology findings and clinical outcomes. J Clin Oncol 2008;26: 4124-4130.

3 Jantunen E, Wiklund T, Juvonen E, Putkonen M, Lehtinen T, Kuittinen O, Franssila K, Söderström KO, Leppä S, Elonen E, Remes K, Nousiainen T: Autologous stem cell transplantation in adult patients with peripheral T-cell lymphoma: a nation-wide survey. Bone Marrow Transplant 2004;33: 405-410.

-4 Rudiger T, Weisenburger DD, Anderson JR, Armitage JO, Diebold J, MacLennan KA, Nathwani BN, Ullrich F, Müller-Hermelink HK Peripheral T-cell lymphoma (excluding anaplastic large-cell lymphoma): results from the Non-Hodgkin's Lymphoma Classification Project. Ann Oncol 2002;13:140-149.

5 Gisselbrecht C, Gaulard P, Lepage E, Coiffier B, Brière J, Haioun C, Cazals-Hatem D, Bosly A, Xerri L, Tilly H, Berger F, Bouhabdallah R, Diebold J: Prognostic significance of T-cell phenotype in aggressive non-Hodgkin's lymphomas. Blood 1998;92:76-82.

6 Intragumtornchai $\mathrm{T}$, Rotnakkarin P, Sutcharitchan P, Wannagrairoj P: Prognostic significance of the immunophenotype versus the
International Prognostic Index in aggressive non-Hodgkin's lymphoma. Clin Lymphoma 2003;4:52-55.

7 Isobe K, Tamaru J, Harigaya K, Mikata A, Ito $\mathrm{H}$ : Clinicopathological evaluation of the revised European-American classification of lymphoid neoplasms (REAL) in Japan. Leuk Lymphoma 1999;34:143-149.

$\checkmark 8$ Lippman SM, Miller TP, Spier CM, Slymen DJ, Grogan TM: The prognostic significance of the immunotype in diffuse large-cell lymphoma: a comparative study of the T-cell and B-cell phenotype. Blood 1988;72:436-441.

>9 Escalón MP, Liu NS, Yang Y, Hess M, Walker PL, Smith TL, Dang NH: Prognostic factors and treatment of patients with T-cell non-Hodgkin lymphoma: the M.D. Anderson Cancer experience. Cancer 2005;103:2091-2098. 
-10 Schmitz N, Trümper L, Ziepert M, Nickelsen M, Ho AD, Metzner B, Peter N, Loeffler M, Rosenwald A, Pfreundschuh M: Treatment and prognosis of mature T-cell and NK-cell lymphoma: an analysis of patients with T-cell lymphoma treated in studies of the German High-Grade Non-Hodgkin Lymphoma Study Group. Blood 2010;116:3418-3425.

11 Vose JM: International Peripheral T-Cell Lymphoma (PTCL) Clinical and Pathologic Review Project: poor outcome by prognostic indices and lack of efficacy with anthracyclines. Blood 2005;106:a811.

12 Vose JM, Peterson C, Bierman PJ, Weisenburger DD, Linder J, Harrington D, Vaughan WP, Kessinger A, Armitage JO: Comparison of high-dose therapy and autologous bone marrow transplantation for T-cell and B-cell non-Hodgkin's lymphomas. Blood 1990;76: 424-431.

13 Fanin R, Ruiz de Elvira MC, Sperotto A, Baccarani M, Goldstone A: Autologous stem cell transplantation for $\mathrm{T}$ and null cell CD30-positive anaplastic large cell lymphoma: analysis of 64 adult and paediatric cases reported to the European Group for Blood and Marrow Transplantation (EBMT). Bone Marrow Transplant 1999;23:437-442.

14 Haider K, Zamkoff K, Gentile TC: High dose chemotherapy (HDCT) and autologous stem cell transplant (ASCT) in peripheral T-cell lymphoma (PTCL): a single institution experience. Blood 1999;94:a753.

15 Rodríguez J, Munsell M, Yazji S, Hagemeister FB, Younes A, Andersson B, Giralt S, Gajewski J, de Lima M, Couriel D, Romaguera J, Cabanillas FF, Champlin RE, Khouri IF: Impact of high-dose chemotherapy on peripheral Tcell lymphomas. J Clin Oncol 2001;19:37663770.

16 Jagasia M, Morgan D, Goodman S, Hamilton K, Kinney M, Shyr Y, Stein R, Zic J, Greer J: Histology impacts the outcome of peripheral T-cell lymphomas after high-dose chemotherapy and stem cell transplant. Leuk Lymphoma 2004:45:2261-2267.

17 Blystad AK, Enblad G, Kvaløy S, Berglund A, Delabie J, Holte H, Carlson K, Kvalheim G, Bengtsson M, Hagberg H: High-dose therapy with autologous stem cell transplantation in patients with peripheral $\mathrm{T}$ cell lymphomas. Bone Marrow Transplant 2001;27: 711-716.

- 18 Rodríguez J, Caballero MD, Gutiérrez A, Marín J, Lahuerta JJ, Sureda A, Carreras E, León A, Arranz R, Fernández de Sevilla A, Zuazu J, García-Laraña J, Rifon J, Varela R, Gandarillas M, SanMiguel J, Conde E: Highdose chemotherapy and autologous stem cell transplantation in peripheral T-cell lymphoma: the GEL-TAMO experience. Ann Oncol 2003;14:1768-1775.

-19 Schetelig J, Fetscher S, Reichle A, Berdel WE, Beguin Y, Brunet S, Caballero D, Majolino I, Hagberg H, Johnsen HE, Kimby E, Montserrat E, Stewart D, Copplestone A, Rösler W, Pavel J, Kingreen D, Siegert W: Long-term disease-free survival in patients with angioimmunoblastic T-cell lymphoma after highdose chemotherapy and autologous stem cell transplantation. Haematologica 2003;88 1272-1278.

20 Song KW, Mollee P, Keating A, Crump M: Autologous stem cell transplant for relapsed and refractory peripheral T-cell lymphoma: variable outcome according to pathological subtype. Br J Haematol 2003;120:978-985.

21 Kewalramani T, Zelenetz AD, Teruya-Feldstein J, Hamlin P, Yahalom J, Horwitz S, Nimer SD, Moskowitz CH: Autologous transplantation for relapsed or primary refractory peripheral T-cell lymphoma. Br J Haematol 2006;134:202-207.

22 Deconinck E, Lamy T, Foussard C, Gaillard F, Delwail V, Colombat P, Casassus P, Lemevel A, Brion A, Milpied N: Autologous stem cell transplantation for anaplastic large-cell lymphomas: results of a prospective trial. $\mathrm{Br}$ Haematol 2000;109:736-742.

23 Kahl C, Leithauser M, Wolff D, Steiner B, Hartung G, Casper J, Freund M: Treatment of peripheral T-cell lymphomas (PTCL) with high-dose chemotherapy and autologous or allogeneic hematopoietic transplantation. Ann Hematol 2002;81:646-650.

24 Bang SM, Kim YK, Park YH, Sohn SK, Lee JJ, Cho EK, Ryoo BY, Chung IJ, Yoon SS, Kim HJ, Lee JH, Yoon HJ, Park S: High-dose therapy and autologous stem cell transplantation in Korean patients with aggressive T/NK-cell lymphoma. Leuk Lymphoma 2005;46:1599_ 1604.

25 Corradini P, Tarella C, Zallio F, Dodero A, Zanni M, Valagussa P, Gianni AM, Rambaldi A, Barbui T, Cortelazzo S: Long-term follow-up of patients with peripheral T-cell lymphomas treated up-front with high-dose chemotherapy followed by autologous stem cell transplantation. Leukemia 2006;20:1533-1538.

26 Kim HJ, Bang SM, Lee J, Kwon HC, Suh C, Kim HJ, Lee JH, Ryoo BY, Park YH, Kwon JM, Oh SY, Lee HR, Kim K, Jung CW, Park K, Kim WS: High-dose chemotherapy with autologous stem cell tansplantation in extranodal NK/T-cell lymphoma: a retrospective comparison with non-transplantation cases. Bone Marrow Transplant 2006;37:819-824.

27 Feyler S, Prince HM, Pearce R, Towlson K, Nivison-Smith I, Schey S, Gibson J, Patton N, Bradstock K, Marks DI, Cook G: The role of high-dose therapy and stem cell rescue in the management of T-cell malignant lymphomas: a BSBMT and ABMTRR study. Bone Marrow Transplant 2007;40:443-450.

28 Rodríguez J, Conde E, Gutiérrez A, Arranz R, Gandarillas M, Leon A, Ojanguren J, Sureda A, Carrera D, Bendandi M, Moraleda J, Ribera JM, Albo C, Morales A, García JC, Fernández P, Cañigral G, Bergua J, Caballero MD, Grupo Español de Linfomas/Trasplante Autólogo de Médula Osea: Prolonged survival of patients with angioimmunoblastic T-cell lymphoma after high-dose chemotherapy and autologous stem cell transplantation: the GELTA-
MO experience. Eur J Haematol 2007;78:290296.

29 Rodríguez J, Conde E, Gutiérrez A, Arranz R, León A, Marín J, Bendandi M, Albo C, Caballero MD: The results of consolidation with autologous stem-cell transplantation in patients with peripheral T-cell lymphoma (PTCL) in first complete remission: the Spanish Lymphoma and Autologous Transplantation Group experience. Ann Oncol 2007;18: 652-657.

-30 Rodríguez J, Conde E, Gutiérrez A, Arranz R, León A, Marín J, Bendandi M, Albo C, Caballero MD, Grupo Español de Linfomas/ Trasplante Autólogo de Médula Osea (GELTAMO): Frontline autologous stem cell transplantation in high-risk peripheral T-cell lymphoma: a prospective study from The GelTamo Study Group. Eur J Haematol 2007;79: 32-38.

-31 Kyriakou C, Canals C, Goldstone A, Caballero D, Metzner B, Kobbe G, Kolb HJ, Kienast J, Reimer P, Finke J, Oberg G, Hunter A, Theorin N, Sureda A, Schmitz N, Outcome-Lymphoma Working Party of the European Group for Blood and Marrow Transplantation: Highdose therapy and autologous stem-cell transplantation in angioimmunoblastic lymphoma: complete remission at transplantation is the major determinant of Outcome-Lymphoma Working Party of the European Group for Blood and Marrow Transplantation. J Clin Oncol 2008;26:218-224.

- 32 Lee J, Au WY, Park MJ, Suzumiya J, Nakamura S, Kameoka J, Sakai C, Oshimi K, Kwong YL, Liang R, Yiu H, Wong KH, Cheng HC, Ryoo BY, Suh C, Ko YH, Kim K, Lee JW, Kim WS, Suzuki R: Autologous hematopoietic stem cell transplantation in extranodal natural killer/T cell lymphoma: a multinational, multicenter, matched controlled study. Biol Blood Marrow Transplant 2008; 14: 1356-1364

33 Mercadal S, Briones J, Xicoy B, Pedro C, Escoda L, Estany C, Camós M, Colomo L, Espinosa I, Martínez S, Ribera JM, Martino R, Gutiérrez-García G, Montserrat E, LópezGuillermo A, Grup per l'Estudi dels Limfomes de Catalunya I Balears (GELCAB): Intensive chemotherapy (high-dose $\mathrm{CHOP} /$ ESHAP regimen) followed by autologous stem-cell transplantation in previously untreated patients with peripheral T-cell lymphoma. Ann Oncol 2008; 19:958-963.

34 Niitsu N, Okamoto M, Nakamine H, Aoki S, Motomura S, Hirano M: Clinico-pathologic features and outcome of Japanese patients with peripheral T-cell lymphomas. Hematol Oncol 2008;26:152-158.

- 35 Prochazka V, Faber E, Raida L, Vondrakova J, Kucerova L, Jarosova M, Indrak K, Papajik T: Prolonged survival of patients with peripheral T-cell lymphoma after first-line intensive sequential chemotherapy with autologous stem cell transplantation. Biomed Pap Med Fac Univ Palacky Olomouc Czech Repub 2009;153:63-66. 
>36 Reimer P, Rüdiger T, Geissinger E, Weissinger F, Nerl C, Schmitz N, Engert A, Einsele H, Müller-Hermelink HK, Wilhelm M: Autologous stem-cell transplantation as first-line therapy in peripheral T-cell lymphomas: results of a prospective multicenter study. J Clin Oncol 2009;27:106-113.

>37 Yang DH, Kim WS, Kim SJ, Bae SH, Kim SH, Kim IH, Yoon SS, Mun YC, Shin HJ, Chae YS, Kwak JY, Kim H, Kim MK, Kim JS, Won JH, Lee JJ, Suh CW: Prognostic Factors and Clinical Outcomes of High-Dose Chemotherapy followed by Autologous Stem Cell Transplantation in Patients with Peripheral T Cell Lymphoma, Unspecified: Complete Remission at Transplantation and the Prognostic Index of Peripheral. Biol Blood Marrow Transplant 2009; 15:118-125.

>38 Numata A, Miyamoto T, Ohno Y, Kamimura T, Kamezaki K, Tanimoto T, Takase K, Henzan H, Kato K, Takenaka K, Fukuda T, Harada N, Nagafuji K, Teshima T, Akashi K, Harada M, Eto T, Fukuoka Blood and Marrow Transplantation Group: Long-term outcomes of autologous PBSCT for peripheral Tcell lymphoma: retrospective analysis of the experience of the Fukuoka BMT group. Bone Marrow Transplant 2010;45:311-316.

-39 Prochazka V, Faber E, Raida L, Papajik T, Vondrakova J, Rusinakova Z, Kucerova L, Myslivecek M, Indrak K: Long-term outcome of patients with peripheral T-cell lymphoma treated with first-line intensive chemotherapy with autologous stem cell transplantation. Biomed Pap Med Fac Univ Palacky Olomouc Czech Repub 2011;155:63-69.

40 Parmar MK, Torri V, Stewart L: Extracting summary statistics to perform meta-analyses of the published literature for survival endpoints. Stat Med 1998;17:2815-2834.

-41 Tierney JF, Stewart LA, Ghersi D, Burdett S, Sydes MR: Practical methods for incorporating summary time-to-event data into metaanalysis. Trials 2007;8:16.

42 Deeks J, Higgins J, Altman D: Analysing data undertaking meta-analyses; in Higgins J, Green S (eds): Cochrane Handbook for Systematic Reviews of Interventions. Chichester, John Wiley \& Sons, 2008, pp 243-296.

43 Deeks J, Altman D, Bradburn M: Statistical methods for examining heterogeneity and combining results from several studies in meta-analysis; in Egger M, Davey Smith G, Altman D (eds): Systematic Reviews in Health Care: Meta-Analysis in Context, ed 2. London, BMJ Publication Group, 2001, pp 285312 .
44 d'Amore F, Relander T, Lauritzsen GF, Jantunen E, Hagberg $\mathrm{H}$, Anderson $\mathrm{H}$, Holte $\mathrm{H}$, Österborg A, Merup M, Brown P, Kuittinen O, Erlanson M, Østenstad B, Fagerli UM, Gadeberg OV, Sundström C, Delabie J, Ralfkiaer E, Vornanen M, Toldbod HE: Upfront autologous stem-cell transplantation in peripheral T-cell lymphoma: NLG-T-01. J Clin Oncol 2012;30:3093-3099.

45 Rodríguez J, Caballero MD, Gutierrez A, Gandarillas M, Sierra J, Lopez-Guillermo A, Sureda A, Zuazu J, Marin J, Arranz R, Carreras E, Leon A, De Sevilla AF, San Miguel JF, Conde E, GEL/TAMO Spanish Group: High dose chemotherapy and autologous stem cell transplantation in patients with peripheral T-cell lymphoma not achieving complete response after induction chemotherapy. The GEL-TAMO experience. Haematologica 2003;88:1372-1377.

46 Cheson BD, Horning SJ, Coiffier B, Shipp MA, Fisher RI, Connors JM, Lister TA, Vose J, Grillo-López A, Hagenbeek A, Cabanillas F, Klippensten D, Hiddemann W, Castellino R, Harris NL, Armitage JO, Carter W, Hoppe R Canellos GP: Report of an internationa workshop to standardize response criteria for non-Hodgkin's lymphomas. J Clin Oncol 1999; 17:1244.

47 Abouyabis AN, Shenoy PJ, Sinha R, Flowers CR, Lechowicz MJ: A systematic review and meta-analysis of front-line anthracycline-based chemotherapy regimens for peripheral T-cell lymphoma. ISRN Hematol 2011;2011:623924.

48 Gallamini A, Stelitano C, Calvi R, Bellei M, Mattei D, Vitolo U, Morabito F, Martelli M, Brusamolino E, Iannitto E, Zaja F, Cortelazzo S, Rigacci L, Devizzi L, Todeschini G, Santini G, Brugiatelli M, Federico M, Intergruppo Italiano LinfomiL: Peripheral T-cell lymphoma unspecified (PTCL-U): a new prognostic model from a retrospective multicentric clinical study. Blood 2004;103:2474-2479.

49 Ansell SM, Habermann TM, Kurtin PJ, Witzig TE, Chen MG, Li CY, Inwards DJ, Colgan JP: Predictive capacity of the International Prognostic Factor Index in patients with peripheral T-cell lymphoma. J Clin Oncol 1997; 15:2296-2301.
50 Zaja F, Russo D, Silvestri F, Fanin R, Damiani D, Infanti L, Salmaso F, Mariuzzi L, Di Loreto C, Baccarani M: Retrospective analysis of 23 cases with peripheral T-cell lymphoma, unspecified: clinical characteristics and outcome. Haematologica 1997;82:171-177.

51 Sonnen R, Schmidt WP, Müller-Hermelink $\mathrm{HK}$, Schmitz N: The International Prognostic Index determines the outcome of patients with nodal mature T-cell lymphomas. $\mathrm{Br} \mathrm{J}$ Haematol 2005;29:366-372.

52 Haioun C, Lepage E, Gisselbrecht C, Bastion Y, Coiffier B, Brice P, Bosly A, Dupriez B, Nouvel C, Tilly H, Lederlin P, Biron P, Brière J, Gaulard P, Reyes F: Benefit of autologous bone marrow transplantation over sequential chemotherapy in poor-risk aggressive nonHodgkin's lymphoma: updated results of the prospective study LNH87-2. Groupe d'Etude des Lymphomes de l'Adulte. J Clin Oncol 1997;15:1131-1137.

53 Haioun C, Lepage E, Gisselbrecht C, Salles G, Coiffier B, Brice P, Bosly A, Morel P, Nouvel C, Tilly $\mathrm{H}$, Lederlin $\mathrm{P}$, Sebban $\mathrm{C}$, Brière J, Gaulard P, Reyes F: Survival benefit of highdose therapy in poor-risk aggressive nonHodgkin's lymphoma: final analysis of the prospective LNH87-2 protocol - a groupe d'Etude des Lymphomes de l'Adulte study. J Clin Oncol 2000;18:3025-3030.

54 Santini G, Salvagno L, Leoni P, Chisesi T, De Souza C, Sertoli MR, Rubagotti A, Congiu AM, Centurioni R, Olivieri A, Tedeschi L, Vespignani M, Nati S, Soracco M, Porcellini A, Contu A, Guarnaccia C, Pescosta N, Majolino I, Spriano M, Vimercati R, Rossi E, Zambaldi G, Mangoni L, Rizzoli V: VACOP-B versus VACOP-B plus autologous bone marrow transplantation for advanced diffuse nonHodgkin's lymphoma: results of a prospective randomized trial by the non-Hodgkin's Lymphoma Cooperative Study Group. J Clin Oncol 1998;16:2796-2802.

55 Milpied N, Deconinck E, Gaillard F, Delwail V, Foussard C, Berthou C, Gressin R, Lucas V, Colombat P, Harousseau JL, Groupe OuestEst des Leucémies et des Autres Maladies du Sang: Initial treatment of aggressive lymphoma with high-dose chemotherapy and autologous stem-cell support. N Engl J Med 2004; 350:1287-1295.

56 Jadad AR, Moore RA, Carroll D, Jenkinson C, Reynolds DJ, Gavaghan DJ, McQuay HJ: Assessing the quality of reports of randomized clinical trials: is blinding necessary? Control Clin Trials 1996;17:1-12.
ASCT as the First-Line Treatment for

PTCL: Meta-Analysis Results
Acta Haematol 2014;131:114-125

DOI: $10.1159 / 000353778$ 